\title{
Loss of histidine decarboxylase as a marker of malignant transformation and dedifferentiation of B-cells infiltrating the skin. A case report of a therapy-resistant multiple myeloma complicated by skin infiltration
}

Judit Várkonyi, István Karádi, Katalin Szőcs, István Sugár, Zoltán Sápi, Márta Marschalko, Éva Pállinger, Zsuzsanna Darvas \& András Falus

To cite this article: Judit Várkonyi, István Karádi, Katalin Szőcs, István Sugár, Zoltán Sápi, Márta Marschalko, Éva Pállinger, Zsuzsanna Darvas \& András Falus (2008) Loss of histidine decarboxylase as a marker of malignant transformation and dedifferentiation of B-cells infiltrating the skin. A case report of a therapy-resistant multiple myeloma complicated by skin infiltration, Acta Oncologica, 47:3, 458-461, DOI: 10.1080/02841860701491066

To link to this article: https://doi.org/10.1080/02841860701491066

冓 Published online: 08 Jul 2009.

Submit your article to this journal ¿

Џll Article views: 226

Q View related articles $\longleftarrow$ 


\title{
Loss of histidine decarboxylase as a marker of malignant transformation and dedifferentiation of B-cells infiltrating the skin. A case report of a therapy-resistant multiple myeloma complicated by skin infiltration
}

\author{
JUDIT VÁRKONYI ${ }^{1}$, ISTVÁN KARÁDI ${ }^{1}$, KATALIN SZÖCS ${ }^{1}$, ISTVÁN SUGÁR ${ }^{2}$, \\ ZOLTÁN SÁPI ${ }^{3}$, MÁRTA MARSCHALKO $^{4}$, ÉVA PÁLLINGER ${ }^{5}$, ZSUZSANNA DARVAS ${ }^{5}$ \& \\ ANDRÁS FALUS ${ }^{5}$ \\ ${ }^{1}$ 3rd Department of Internal Medicine, Semmelweis University, Budapest, Hungary, ${ }^{2} 2 n d$ Department of Surgery, \\ Semmelweis University, Budapest, Hungary, ${ }^{3}$ Department of Pathology, St. Fohn's Hospital, Budapest, Hungary, \\ ${ }^{4}$ Department of Dermatology, Semmelweis University, Budapest, Hungary and ${ }^{5}$ Department of Genetics and Cell \\ Immunbiology, Semmelweis University, Budapest, Hungary
}

\section{To the Editor}

Multiple myeloma (MM) is a B-cell lymphoma of matured plasmacytic origin. There is a well described spectrum of cutaneous diseases in $M M$ including cell infiltration and amyloid deposition [1]. Little is known about the basic processes involved that allow malignant plasma cells or lymphomas to grow outside the bone marrow environment. Several experimental models have been used to study this issue [2]. Hedvat et al. found altered gene expression profile pattern in plasma cells growing in extramedullary sites mostly involved in angiogenesis and adhesion [3]. Identification of other tumour-specific alterations required for extramedullary growth would confer better understanding of tumour metastasis. In an earlier study authors found that histidine decarboxylase (HDC)- that is the only enzyme capable of histamine synthesis- is absent from B-lymphocytes infiltrating the skin in a B-cell chronic lymphocytic leukemia patient who developed cutaneous infiltrations in the course of the disease. In contrast to this, those cells that remained in the bone marrow had their HDC activity been preserved [4]. There is evidence that besides histamine being a well known mediator of allergic reactions, may also be involved in certain types of cell proliferations like wound healing, embryonic development and tumor growth [5,6]. There are data confirming that a functioning HDC gene is important in maintaining immune homeostasis [7]. The relation of histamine metabolism and metastatising human plasma cell malignancies has not been examined so far. The case reported here served an appropriate occasion for that.

\section{Case report}

A 70 year-old female multiple myeloma patient type IgG lambda, stage IA, developed purple coloured papular skin infiltrates involving both legs after 2 months ineffective thalidomide and 5 months melphalan plus prednisolone therapy (Figure 1).

The skin infiltrating cells were shown to be plasma cells (Figure 2). There was a significant difference in HDC content comparing the skin infiltrating plasma cells to bone marrow plasma cells: plasma cells infiltrating the skin became HDC negative during tissue invasion (Figures 3,4). A very strong HDC positivity was found among bone marrow plasma cells identified by CD38 and CD138 in contrast to other mononuclear cells (Figures 5,6).

Skin infiltrates came along with other signs of progression, like extension of bony lesions, appearance of subcutaneous nodules, fibronodular 


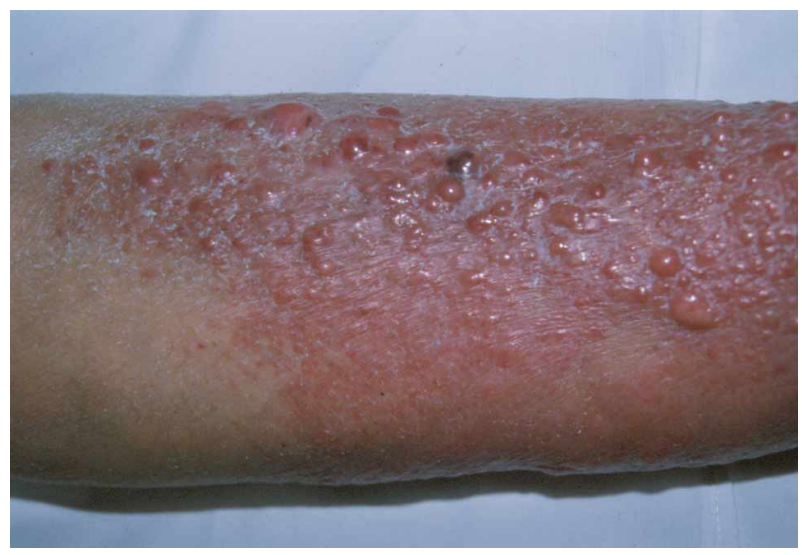

Figure 1. Myelomatous skin infiltrates. On the extensor surfaces of the legs ten serous bullae are seen, of size 10-20 mm overlying erythemato-edematous plaques; this appearance developed in the 11 th month of the disease course.

lung manifestations and the development of heart and renal amyloidosis causing intractable oedema leading eventually to the patient's death.

The disease was refractory to various chemotherapeutic protocols including continuous low dose Melphalan, cyclophosphamide, CVP, M2, VAD, high dose dexamethasone and local bone irradiation. The administration of the cytokine interferon alpha (IFN- $\alpha$ ) had to be stopped because of intolerance. Twenty two months from diagnosis the patient died of cardiac and renal insufficiency.

\section{Laboratory results}

Initially WBC: $4.3 \times 10^{9} / 1, \mathrm{PCV}: 39 \%$, Hgb $133 \mathrm{mg} /$ $\mathrm{dl}$, Platelet count $236 \times 10^{9} / 1$, bone marrow infiltration rate: $30 \%, \operatorname{IgG}: 1925, \operatorname{IgA}: 15, \operatorname{IgM}: 28 \mathrm{mg} / \mathrm{dl}$. Preterminally the degree of proteinuria was over $1.0 \mathrm{~g} / 24 \mathrm{~h}$, pancytopenia developed and the $\operatorname{IgG}$ concentration had also risen up to $3090 \mathrm{mg} / \mathrm{dl}$.

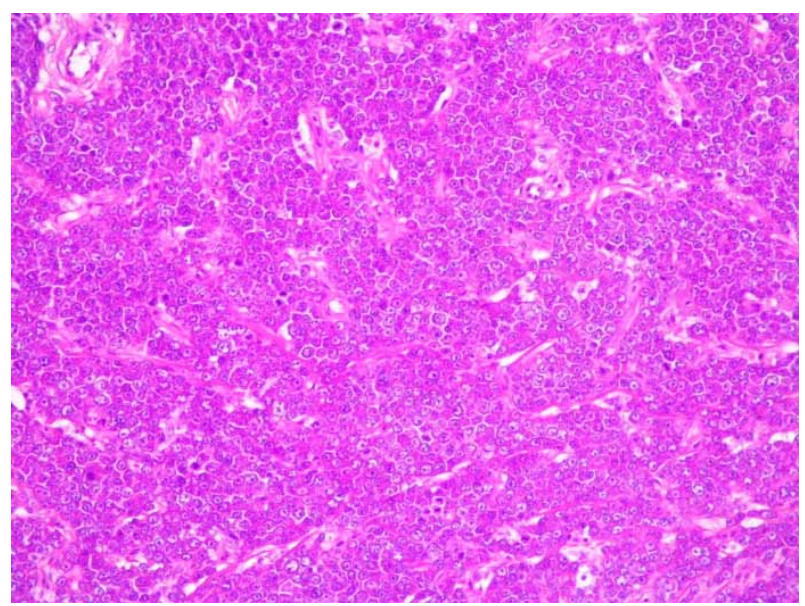

Figure 2. Biopsy specimen of the involved skin with a plasma cell infiltrate. HE staining.

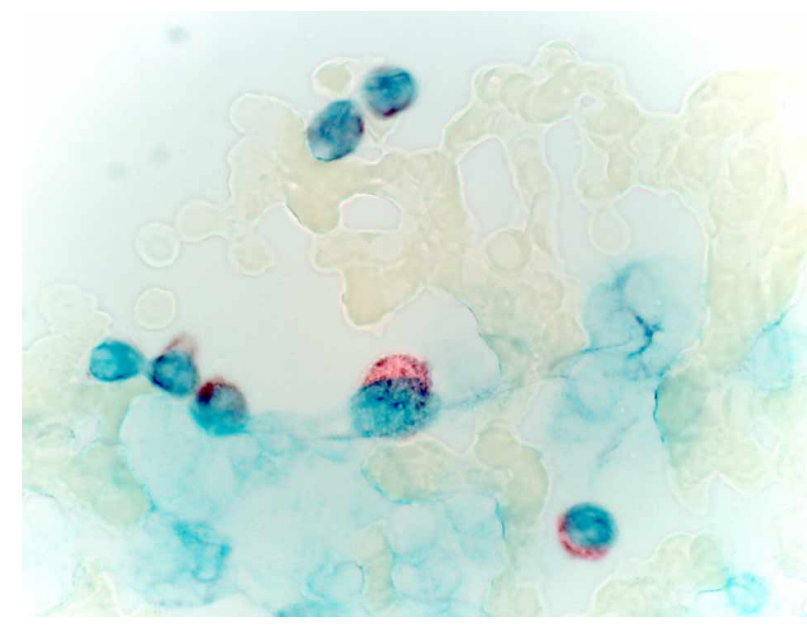

Figure 3. Histidine decarboxylase activity in bone marrow smear with $30 \%$ plasma cell infiltration rate. Plasma cells are shown to be HDC positive. Immunohistochemical staining.

(Between the two end points the $M$ component was around $11 \mathrm{mg} / \mathrm{dl}$ for 8 months.) ECG showed low voltage. There were focal sparkling, pericardial fluid, dilated atria and concentric left ventricular hypertrophy seen on echocardiography as evidences of amyloidosis.

\section{Discussion}

The case presented here raises three questions: 1) the pathologic mechanism of epidermoinvasivity; 2) the role of histamine metabolism in the malignant process and 3) the therapy for secondary B-cell cutaneous lesions.

Secondary cutaneous infiltration developing in the course of a patient with B-cell neoplasm is a relatively rare event. In contrast to primary cutaneous infiltrations the secondary form in a

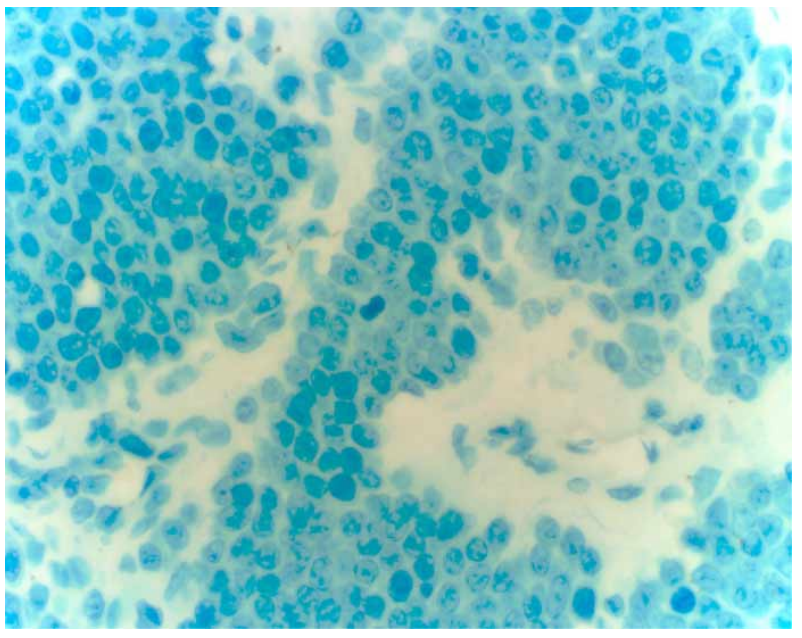

Figure 4. The lack of Histidine decarboxylase immunoreactivity in the skin specimen infiltrated with plasma cells. Immunohistochemical staining. 


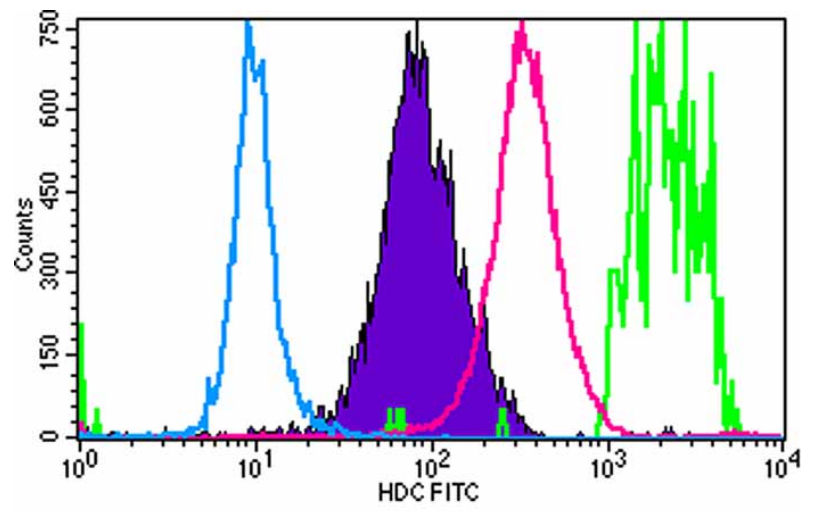

\begin{tabular}{llll} 
Key Name & & Paraneter & Gate \\
\hline & CD38licHDC 2.022 & FL1H & ly-blast population \\
& CD38licHDC2.022 & FL1H & CD38+cells \\
& CD38licHDC2.022 & FL1H & granulocytes \\
& ic c Y.019 & FL1H & ly-blast population
\end{tabular}

Figure 5. Flow cytometric analysis of bone marrow cells of the myeloma patient in respect of their HDC content. Plasma cells are identified by CD38. In contrast to the FITC bound anti-chicken antiserum showing background activity, all the cells had HDC content but the CD38 malignant plasma cells had the highest one.

lymphoma patient usually means transformation of the disease, heralding a poor prognosis $[4,8]$. In all those cases had already been published, the absence of HDC in the cutaneous lesions was confirmed in contrast to lymphoma cells residing in the bone marrow, similarly to the case presented here. This phenomenon may be one of the alterations that allow the cells to become epidermotropic.

The presence of HDC in both benign and malignant cell proliferations has been well documented. Intracellular histamine may bind to binding sites
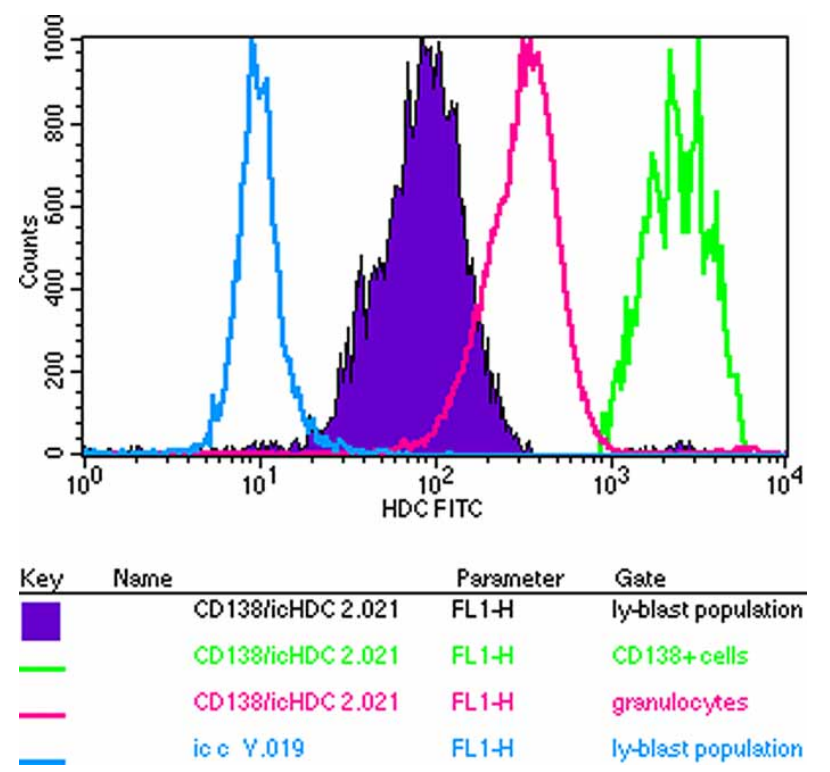

Figure 6. Flow cytometric analysis of bone marrow cells of the myeloma patient in respect of their HDC content. Plasma cells are identified by CD138 whose HDC content is the highest of all. other than histamine receptors. Ligands for the intracellular histamine receptor/binding sites appear to represent a new class of tumor promoting agents or perhaps might act as inhibitors [9]. The possible role of antihistamines and HDC inhibitors as antiproliferative agents is controversial and still under evaluation. Histidinol, an intracellular histamine receptor $\mathrm{H}_{\mathrm{IC}}$ antagonist, has an antiproliferative effect itself and also enhances cytotoxicity of antineoplastic drugs in combination. This effect is not uniform; it depends on cell type and dose [10]. Histamine potentiates alpha IFN-mediated antitumor effects, which may be due to histamine enhancement of NK and T-cell cytotoxicity [11]. This effect had been exploited in a trial where histamine was give to NHL patients previously treated with chemotherapy, to maintain remission [12].

IFN- $\alpha$ does not eliminate malignant cells but inhibits their overgrowth in culture [13]. This could be one possible explanation for the clinical finding in the B-CLL case with cutaneous infiltrations responding to INF- $\alpha$ as it has been reported earlier [4]. In that case the skin infiltrations disappeared within a month without healing of the leukemia process itself.

\section{Conclusion}

What we could learn from the case presented here is that epidermoinvasive plasma cells lose their HDC content. This is an acquired characteristic similar to the upregulation of adhesion molecules like CD44 which renders them able to disseminate and capable of skin invasion [14]. The acquired loss of HDC expression in the infiltrative cells points out that changes may occur not only on cell surface levelinvolving adhesion and angiogenesis- but even in the metabolism of such conservative molecules as HDC. Thus, extramedullary myeloma can be biologically altered from myeloma remaining in situ suggesting that the therapeutic approach should also be different. Hopefully further studies on histamine metabolism might lead to the development of more targeted therapy to lymphoma patients including those with cutanous infiltrations.
Abbreviations
HDC: histidine decarboxylase, IgY: polyclonal chicken antibody
IFN- $\alpha$ : interferon alpha, MM: multiple myeloma NHL: non-Hodgkin lymphoma
CVP: Cyclophosphamide, Vincristine, Prednison, M2 protocol: Melphalan, BCNU, Vincristine and Prednisolone, VAD-protocol: Vincristine, Adriamy- cin, Prednisolone 


\section{References}

[1] Bayer-Garner IB, Smoller BR. The spectrum of cutaneous disease in multiple myeloma. J Am Acad Dermatol 2003;48: 497-507.

[2] Gado K, Silva S, Pálóczi K, et al. Mouse plasmocytoma: An experimental model of human multiple myeloma. Haematologica $2001 ; 86: 227-36$.

[3] Hedvat CV, Comenzo RL, Teruya-Feldstein J, Olshen AB, Ely SA, Osman K, et al. Insight into extramedullary tumour cell growth revealed by expression profiling of human plasmocytomas and multiple myeloma. Brit J Haematol 2003;122:728-44.

[4] Várkonyi J, Zalatnai A, Tímár J, et al. Secondary cutaneous infiltration in B cell chronic lymphocytic leukemia. Acta Haematol 2000;103:116-21.

[5] Kahlson G. A place for histamine in normal physiology. Lancet 1960;I:67-71.

[6] Bartholeyns J, Bouclier M. Involvement of histamine in growth of mouse and rat tumors: Antitumoral properties of monofluoromethylhistidine, an enzyme-activated irreversible inhibitor of histidine decarboxylase. Carcer Res 1984;44: $639-45$.

[7] Quintana FJ, Buzas E, Prohászka Z, Bíró A, Kocsis J, Füst $\mathrm{G}$, et al. Knock-out of the histidine decarboxylase gene modofies the repertoire of natural autoantibodies. J Autoimmun 2004;22:297-305.
[8] Tarkovács G, Ujvary B, Panczel P, Berczi L, Palinger E, Matolcsy A, et al. Losing histidine decarboxylase immunreactivity appears to be a regularity in the development of secondary cutaneous B-cell lymphoma. EORTC Cutaneous Lymphoma Task Force Clinical Meeting Budapest, 22-24 September 2006.

[9] Bencsáth M, Pálóczi K, Szalai CS, Szenthe A, Szeberényi J, Falus A. Histidine decarboxylase in peripheral lymphocytes of healthy individuals and chronic lymphoid leukemia patients. Pathol Oncol Res 1998;4:121-4.

[10] Brandes LJ, LaBella FS, Warrington RC. Increased therapeutic index of antineoplastic drugs in combination with intracellular histamine antagonists. J Natl Cancer Inst 1991; 83:1329-36.

[11] Naredi P. Histamine as adjunct to immunotherapy. Semin Oncol 2002;29:31-4.

[12] Ahlberg R, MacNamara B, Andersson M, et al. Stimulation of T-cell cytokine production and NK-cell function by IL-2, IFN- $\alpha$ and histamine treatment. Hematol J 2003;4:295-302.

[13] Cornelissen JJ, Ploemacher RE, Wognum BW, Borsboom A, Kluin-Nelemans HC, Hagemeijer A, et al. An in vitro model for cytogenetic conversion in CML. IFN $\alpha$ preferentially inhibits the outgrowth of malignant stem cells preserved in long term culture. J Clin Invest 1998;102:976-83.

[14] Drillenburg P, Pals ST. Cell adhesion receptors in lymphoma dissemination. Blood 2000;95:1900-10.

\title{
EBV positivity in primary cutaneous large B-cell lymphoma with immunophenotypic features of leg type: An isolated incidence or something more significant?
}

\author{
SUJATA GAITONDE ${ }^{1}$, SRAVANKUMAR KAVURI ${ }^{1}$, VICTORIA ALAGIOZIAN- \\ ANGELOVA $^{1}$, DAVID PEACE ${ }^{2} \&$ SOPHIE WOROBEC ${ }^{3}$ \\ ${ }^{1}$ Department of Pathology, University of Illinois, Chicago, USA, ${ }^{2}$ Department of Medicine, University of Illinois, Chicago, \\ USA, and ${ }^{3}$ Department of Dermatology, University of Illinois, Chicago, USA
}

To the Editor,

The WHO-EORTC classification divides cutaneous B-cell lymphomas into four categories of which primary cutaneous diffuse large B-cell lymphoma, leg type (PCLBCL, leg type) characteristically involves lower legs of elderly women and shows a predominance of confluent sheets of medium sized to large cells with round nuclei and prominent nucleoli resembling centroblasts and/ or immunoblasts. The neoplastic B-cells of PCLBCL, leg type have characteristic immunophenotype which readily differentiates them from other subtypes of primary cutaneous diffuse large B-cell lymphomas. The overall prognosis in this group is poor with a tendency to extracutaneous dissemination. An association of PCLBCL, leg type with Epstein Barr virus (EBV) has not been previously described. We report an unusual case of PCLBCL with immunophenotypic features of leg type with EBV positivity in the neoplastic B-cells by in situ hybridization. A fifty-five year old Caucasian male presented with a subcutaneous nodule on his right thigh which was comple-

Correspondence: University of Illinois at Chicago, Department of Pathology (M/C 847), Medicine and Dermatology, 840 South Wood Street, Room 110 CSN, Chicago, IL 60612 USA. Tel: +1 312996 4206. E-mail: sgaitond@uic.edu 